\title{
A RESPONSABILIDADE CIVIL E CRIMINAL NA INTERNET: O PAPEL DO JUDICIÁRIO BRASILEIRO
}

Marlene Helena França ${ }^{1}$

\begin{abstract}
Resumo
A internet se transformou nos últimos anos numa importante ferramenta no processo de comunicação entre as pessoas, bem como, na realização dos mais variados negócios. Paralelo aos benefícios em razão da abrangência por ela alcançada, também são contabilizados uma série de malefícios, sobretudo, o que diz respeito ao seu mau uso. Simultaneamente com o benefício desse serviço surgiram os crimes virtuais, porém, o ordenamento jurídico pátrio não acompanhou a velocidade de crescimento do uso desta importante tecnologia. Existem projetos de lei que aguardam serem sancionados a mais de três anos e, enquanto isso, os criminosos se aperfeiçoam cada dia mais. O resultado desta disparidade é verificado no número de casos de pessoas lesadas e de indivíduos responsabilizados por estes crimes. Assim, este artigo versa sobre a responsabilidade civil e criminal relacionada à internet, cujo recorte repousa nas condutas adotadas pelos internautas em relação a alguns aspectos, fazendo do espaço virtual uma "terra sem lei". Pretende-se discutir o significado de responsabilidade civil e criminal e como os tribunais brasileiros tem se posicionado em relação a esses crimes. Utilizou-se da revisão bibliográfica como aporte metodológico, bem como, a abordagem hipotético-dedutivo, cuja toma por base a percepção e o aprofundamento teórico de um determinado problema. O resultado dessa análise mostrou que as pessoas precisam estar atentas para as condutas adotadas na internet e assumir responsabilidades diante de seus atos, pois ninguém é obrigado a sofrer todo tipo de ofensa, tampouco ficar indiferente em face da mesma.
\end{abstract}

Palavras-chave: Responsabilidade civil. Responsabilidade criminal. Internet.

\section{Introdução}

É indiscutível o fato de que a internet tornou-se, nas últimas décadas, um dos principais meios de comunicação, quiçá, o principal e, em relação ao qual, as pessoas das mais diferentes classes sociais, não conseguem se desprender tão facilmente, tornando-se, inclusive, um hábito cotidiano, comparado com a

\footnotetext{
${ }^{1}$ Profa. Adjunta do Departamento de Habilitação Pedagógica/CE/UFPB. Doutora em Sociologia pela UFPB. Possui graduação em Direito (2017) e em Serviço Social (2000) pela Universidade Federal da Paraíba. Mestrado em Serviço Social pela Universidade Federal da Paraíba (2003). Atualmente é Professora Adjunto III da Universidade Federal da Paraíba, lotada no Departamento de Habilitações Pedagógicas-CE. Integra integrar o Banco de Avaliadores do Sistema Nacional de Avaliação da Educação Superior - BASis/INEP/MEC. Integra o Conselho Nacional de Desenvolvimento Científico e Tecnológico. Professora Pesquisadora do curso de Pedagogia, modalidade a Distância da UFPB. ViceCoordenadora do Núcleo de Direitos Humanos da UFPB. Coordenadora do Projeto de pesquisa - PIBIC/CNPq, intitulado: Um Estudo das Mulheres encarceradas no Estado da Paraíba. Membro do NCDH. Consultora da UNESCO. Universidade Federal da Paraíba - UFPB - Paraíba- Brasil. ORCID iD: http://orcid.org/0000-0003-1844-3451 Lattes: http://lattes.cnpq.br/7965148318489241 E-mail: marlenecel@hotmail.com
} 
necessidade de comer, tomar banho, entre outros. Outra constatação que se faz é o impacto diretamente causado nas relações por ela estabelecidas.

Nessa linha de raciocínio, pretende-se discutir acerca da responsabilidade civil e da responsabilidade criminal e, mais especialmente aquelas relacionadas à internet e, os desdobramentos delas decorrentes. Para tanto, buscar-se-á nos autores que vem se debruçando sobre a temática, novos elementos de discussão, visando o aprofundamento do tema.

No entanto, é preciso destacar que a maior motivação da autora para a escolha desse objeto de estudo se justifica em razão de constatar a quantidade de processos judiciais envolvendo crimes da internet e muitas denúncias que ainda estão sendo investigadas. Em relação a essa questão pretende-se demonstrar os principais aspectos que estão envolvidos em torno dessa problemática, tomando por base alguns casos que já foram objeto de decisões nos tribunais.

Como cediço, inegável em tempos atuais a corrente prática delitiva por meio da internet, às vezes até como um novo meio instrumental de operacionalização do crime, às vezes o surgimento de uma nova modalidade de tipificação delitiva, o que recomenda maior estudo e aprofundamento desta eclosão criminosa que certamente não parará por aí. A este respeito, incisivas são as práticas delitivas prescritas pelos hackers ou outros 'criminosos virtuais', que vez por outra se utilizam de diversas artimanhas de informática a perpetrar infrações aos direitos da personalidade, direito à intimidade e privacidade, e mesmo até ao direito de propriedade, sendo inúmeros os casos de fraude jurídica promovida pela internet ora capituladas como furto mediante fraude, ora como estelionato, a depender da real intenção deliberada e consciente na aferição da vantagem ilícita e do modus operandi.

Como se não bastasse, também hoje cristalina a prática do bullying virtual, ou cyberbullying, que, em grande parte das vezes, se reveste de ato infracional passível de repreensão pelo Código Penal brasileiro ou mesmo, a depender da legitimidade, pelo Estatuto da Criança e do Adolescente - ECA, o que não descaracteriza sua inserção penal como cybercrime. Por uma ou outra via jurídica, fato é que o Direito não pode se distanciar da finalidade primacial de pacificação e resolução da lide, muito menos encontrar impedimento a tanto, devendo ser utilizada, por ora, nossa legislação vigente, a coibir a crescente prática destas infrações criminosas.

No Brasil, embora a oferta em escala do acesso à rede ter se iniciado apenas em 1995, de acordo com dados divulgados em 2013, na Pesquisa Nacional por Amostra de Domicílios, feita pelo Instituto Brasileiro de Geografia e Estatística (IBGE), existem mais de 80 milhões de usuários, com taxa de 
crescimento de $5 \%$ ao ano ${ }^{2}$.

Então, quando esses números são confrontados com a população brasileira, tendo também como parâmetro o censo feito pelo IBGE em 2012, que indicou uma população de mais de 190 milhões de brasileiros e uma taxa de crescimento anual de $1,23 \%^{3}$, leva-se a crer que, nos próximos anos 5 anos, a maioria da população nacional será usuária da rede. É preciso salientar ainda, que este fenômeno de popularidade ultrapassa os limites geográficos do território brasileiro e se repete em escala global, ainda mais se considerarmos o fato de que muitos governantes têm investido e facilitado cada vez mais o acesso a esse tipo de serviço, inclusive nas periferias das grandes cidades, é possível encontrar locais com acesso à internet gratuita em que a população de baixa renda pode fazer uso.

No início, o perfil do internauta era de passividade ante o espaço virtual. Geralmente, buscava somente, de uma forma despretenciosa, obter informações na rede mundial. Entretanto, em pouco tempo, esse comportamento deu lugar ao internauta essencialmente ativo, estimulado, sobretudo, pela criação de diversos espaços públicos de interação como o twitter, ofacebook, o linkedin, os blogs e mais recentemente o instagram. São nesses ambientes, que hoje os usuários costumam emitir de modo mais contundente e até preconceituosa, suas opiniões sobre questões políticas, profissionais, cotidianas e afetivas, envolvendo a vida das pessoas.

Neste estudo, pretende-se responder a algumas questões norteadoras, tais como: Por que as pessoas falam tão abertamente da sua vida pessoal para outras que, sequer sabem o nome? O que leva alguém a opinar sobre a roupa, a maquiagem, cabelo, pele, etc., de uma pessoa com quem não tem nenhum contato? O que justifica tanta exposição? Quais as razões que motivam uma pessoa a dar palpites na vida pessoal de outra, aconselhando o que deve ser feito em relação ao problema dessa segunda? É na tentativa de responder a essas indagações que este estudo se desenhou.

\section{Sobre a Responsabilidade Civil e Criminal: Os Crimes pela internet}

Antes de aprofundar a discussão acerca do uso crescente da internet pelas pessoas e das

\footnotetext{
2 Pnad 2013: Internet pelo celular é utilizada em mais da metade dos domicílios que acessam a Rede. Disponível em: $<$ https://agenciadenoticias.ibge.gov.br/agencia-sala-de-imprensa/2013-agencia-de-noticias/releases/9840-pnad-2013internet-pelo-celular-e-utilizada-em-mais-da-metade-dos-domicilios-que-acessam-a-rede>. Acesso em: 12 dez. 2019. ${ }^{3}$ Disponível em: <http://www.censo2012.ibge.gov.br/resultados_do_censo2012.php>. Acesso em: 12 dez. 2019.
} 
implicações decorrentes desse uso, convém discutir o significado da responsabilidade civil na visão de alguns doutrinadores.

Nesta perspectiva, a responsabilidade civil pode ser entendida como toda atividade humana que deve ser feita com responsabilidade; tal instituto integra o direito das obrigações e acarreta para o infrator o dever de reparar patrimonialmente o dano causado, ou seja, trata-se de uma obrigação pessoal que acarretará em perdas e danos se houver o nexo de causalidade entre o ato praticado pelo infrator e o dano sofrido pela vítima.

De acordo com Lopes e Gonçalves (2009), o termo responsabilidade deve ser entendido como restituição ou compensação de algo que foi retirado de alguém. Como já dito, a responsabilidade tem por finalidade restituir ou ressarcir algo em benefício da pessoa que sofreu o dano. Porém, se o dano atinge o patrimônio de alguém, é chamado de dano material. Imagine uma situação em que alguém envie um arquivo malicioso (o chamado malware) a outra pessoa, causando problemas no computador do destinatário, o qual será obrigado a contratar alguém para resolvê-lo. O remetente do arquivo poderá ser condenado a pagar os danos que causou à vítima.

Outra situação em que pode surgir responsabilidade civil é quando alguém causa dano psicológico em outra pessoa, comumente conhecido por dano moral.Um exemplo que ilustra essa situação ocorre quando alguém ofende a honra de outra pessoa em rede social ou blog, em mensagens, comentários, respostas ou por qualquer outra forma.

Assim, a responsabilidade civil, nasce com a ocorrência de dano e gera direito à indenização da vítima por parte de quem ofendeu. Sua consequência é de natureza estritamente econômica, patrimonial.

Vale salientar, que um mesmo ato pode gerar, ao mesmo tempo, dano material e dano moral. Em relação a esta questão, foi aprovada a Súmula 37do Superior Tribunal de Justiça. Esta Súmula prevê a possibilidade de haver indenização tanto por dano material quanto por dano moral, mesmo que causados por um só ato.

A responsabilidade penal se caracteriza quando alguém pratica um ilícito definido em uma lei como crime ou contravenção penal. Neste caso, além de possível indenização à vítima, o autor poderá responder às penalidades previstas na legislação penal.

Cabe esclarecer, que embora o Brasil e outros países não tenham ainda lei específica para crimes praticados pela internet, as leis penais em geral costumam ser inteiramente aplicáveis aos atos praticados pela internet. Assim, o fato de não existir lei específica para a internet não implica dizer que as pessoas deixarão de responder por seus atos no chamado mundo virtual.

Se alguém ofende a honra de outrem e, desse modo comete crime previsto na legislação penal, é vol.13, $\mathrm{n}^{\circ} .01$,Riode Janeiro,2020.pp. 480-507 
indiferente se essa conduta foi na presença da vítima, através de carta, pela imprensa, pela internet ououtro meio. Em qualquer dos casos, poderá ser responsabilizada. Em alguns países, as leis podem estabelecer diferenças a depender da forma como o crime seja cometido, mas, geralmente, as penas costumam ser as mesmas. No caso do Brasil, não há distinção para crimes praticados pela internet ou por outro meio.

Diferentemente da responsabilidade civil, na responsabilidade penal, se alguém for ofendido na internet ou sofrer algum outro dano, poderá optar por ajuizar apenas ação de indenização contra o autor do fato. Para o juiz condenar alguém a pagar indenização, não é indispensável que exista condenação criminal.

Provavelmente, os crimes mais frequentes na internet, são os chamados crimes contra a honra. Com o aumento cada vez maior do uso das redes sociais, aliado a falta de maturidade e de bom senso dos usuários, é mais do que esperado que alguns se excedam em seus comentários e acabem atingindo a reputação alheia. Nessas situações, os autores da ofensa estarão sujeitos tanto às consequências criminais (ou seja, ao cumprimento de pena) quanto civis (o pagamento de indenização à vítima) de seu ato.

Se a ofensa for direcionada a um cidadão comum, a lei brasileira estabelece que a ação penal sejapromovida pela vítima, por meio de advogado por ela contratado. É o que se chama ação penal privada, a qual se inicia por petição denominada Queixa-crime.

\subsection{Diferenças entre Responsabilidade Civil e Penal}

Conforme aponta Lopes; Gonçalves (2009), entre os romanos não havia distinção alguma entre responsabilidade civil e responsabilidade penal, inclusive a compensação pecuniária não passava de uma pena imposta ao infrator do dano. Com o passar do tempo surgiram diferentes teses e, embora a responsabilidade continuasse sendo penal, a indenização pecuniária passou a ser a única forma de punir o infrator do ato lesivo não criminoso. A respeito da distinção entre responsabilidade civil e penal, Aguiar Dias adverte:

Para efeito da punição ou da reparação, isto é, para aplicar uma ou outra forma de restauração da ordem social é que se distingue: a sociedade toma conta daquilo que a atinge diretamente, deixando ao particular a ação para restabelecer-se, à custa do ofensor, no estado anterior a ofensa (...) isto porque o Estado ainda mantém um regime político que explica a sua não intervenção. Restabelecida a vítima na situação anterior, está desfeito o desequilíbrio experimentado.

Então, como é possível observar, uma ou outra forma de reparação será adotada nos casos em 
que forem cometidos crimes nas redes sociais. O mesmo ocorre nos crimes ocorridos em outras esferas sociais. O que é preciso deixar claro é o fato de que a sociedade está muito atenta em relação às condutas reprovadas socialmente, sobretudo quando tais condutas atacam a dignidade e os direitos personalíssimos da pessoa.

Um exemplo que pode ser dado mostrando a diferença entre responsabilidade civil e criminal é a colisão entre veículos. $\mathrm{O}$ fato pode gerar a responsabilidade civil do culpado, que será obrigado a pagar as despesas com o conserto do outro veículo e todos os danos causados, mas também por acarretar a sua responsabilidade penal, caso alguém tenha ficado com algum ferimento ou tenha configurou o crime do artigo 129, $\S 6^{\circ}$ do Código Penal ou do crime do artigo 121, $3^{\circ}$ do mesmo código. Em outras palavras, pode-se afirmar, nos casos em que envolve uma ação ou omissão, o agente pode vir a responder civil e penalmente pelo dano causado.

O conceito de ato ilícito pode ser encontrado nos 186 e 187 do Código Civil de 2002. Neste sentido, o artigo de 186 prevê: "aquele que, por ação ou omissão voluntária, negligência ou imprudência, violar direito e causar dano a outrem, ainda que exclusivamente moral, comete ato ilícito”. Já o art. 187 diz que, "também comete ato ilícito o titular de um direito que, ao exercê-lo, excede manifestamente os limites impostos pelo seu fim econômico ou social, pela boa-fé ou pelos bons costumes”. (BRASIL, CÓDIGO CIVIL/2002).

Com base nessa prescrição, o legislador achou por bem que deveria editar normas acerca da responsabilidade civil, como uma forma de "frear as condutas ilícitas". O art. 927 do mesmo código civil é um exemplo claro dessa tentativa: "Aquele que, por ato ilícito, causar dano a outrem, fica obrigado a repará-lo". Como é possível observar o legislador não se furtou em atender o clamor da sociedade que durante um bom tempo gritou por punição (no âmbito civil ou penal)contra aqueles que insistiam em ofender a honra ou praticar o mal contra outrem.

O Parágrafo único do art. 927 não deixa dúvidas sobre a obrigação de reparar o dano, independentemente de culpa, nos casos especificados em lei, ou quando a atividade normalmente desenvolvida pelo autor do dano implicar, por sua natureza, risco para os direitos de outrem.

A responsabilidade penal tem quase o mesmo fundamento da responsabilidade civil. O elemento o que as torna diferente repousa nas condições em que elas surgem. Acerca dessa distinção, Aguiar Dias (1979) adverte que uma é mais exigente do que a outra quanto ao aperfeiçoamento dos requisitos. No caso da responsabilidade penal, o agente infringe uma norma de direito público. Neste caso, o interesse lesado é a sociedade. Já na responsabilidade civil, o interesse tutelado é o privado, dando ao prejudicado a chance de requerer a reparação, se assim desejar. 
É possível que o agente, ao infringir uma norma civil, transgrida também a lei penal tornando-se ao mesmo tempo, obrigado civil e penalmente. A distinção entre a responsabilidade civil e penal também se dá noutra esfera. Enquanto a penal é de natureza pessoal e intransferível, isto é, o réu responde com a privação da sua liberdade, a responsabilidade civil é ordem patrimonial, o que implica dizer que, se o autor do dano não possuir bens, a vítima ofendidadificilmente será ressarcida.

Outro requisito que caracteriza a responsabilidade penal é a tipicidade; entendido como um dos elementos genéricos do crime. Isso implica dizer que é necessário uma relação "umbilical” entre o fato concreto e o tipo penal. Mas, o que é isso? Na verdade, alguém só poderá responder por um crime cometido na esfera penal se for comprovado uma estrita relação entre o fato que ensejou o dano e a tipicidade penal ou ainda, uma intenção deliberada de alguém no cometimento da prática delituosa. Já na esfera cível, conforme expressa o art. 196, qualquer ação ou omissão pode gerar responsabilidade, a partir do momento em que há violação de direito ou prejuízo a alguém, independentemente de culpa.

A imputabilidade também é tratada de modo diferente entre os institutos. Somente os maiores de 18 anos são responsáveis civil e criminalmente por seus atos.

No que tange à culpabilidade, no âmbito civil, ela é mais ampla. Já na esfera criminal nem toda culpa traduz na condenação do réu, pois se exige certo grau ou intensidade em relação ao ato praticado.

\section{O espaço público virtual: Território sem Lei?}

A participação político-social, que possibilite qualquer pessoa concretizar a liberdade de expressão e de informação, transforma a internet na principal ferramenta para a manifestação da cidadania, cuja concepção clássica está ligada à efetiva participação político social do indivíduo na tomada de decisões. Para a maioria dos teóricos das ciências sociais, o acesso à rede se configura como o reconhecimento de um direito fundamental, que é o de comunicar-se e poder expressar livremente sua opinião; obviamente desde que cause ofensa a ninguém.

No entanto, o propósito desse estudo não é o de questionar a essencialidade da internet como espaço público concretizador de ideais constitucionais de participação e de emancipação do cidadão. Até porque, o direito à privacidade e à liberdade de expressão são pressupostos para o pleno exercício do direito de acesso à internet. Nossa inquietação está na forma equivocada de como alguns têm utilizado o espaço virtual.

É cediço lembrar que o espaço público virtual permite que o cidadão se manifeste, sem nenhuma censura prévia, sobre qualquer assunto que considerar relevante. Para tanto, costuma fazê-lo em um 
ambiente físico completamente seguro, normalmente em sua própria casa. Essa privacidade tão propalada e defendida pelo usuário, dá a ele uma falsa impressão de que não só estará seguro fisicamente, para publicar o que pretender como uma falsa ideia de que o ciberespaço confere invisibilidade, gerando uma falsa impressão de que não será descoberto, caso venha a praticar uma conduta ilícita.

Essa liberdade de pensamento e de expressão no espaço virtual, aliada a um possível anonimato, leva o usuário a acreditar de que a internet é um território sem lei, um ambiente social paralelo constituído pela total ausência do Estado e de seu poder de polícia. E que ainda, não há razão para fazer comparações entre a vida real e a internet, pois representam dimensões distintas e, portanto, as regras do mundo real não se aplicam ao mundo virtual, tampouco os valores e concepções éticas.

Inquestionavelmente essa visão está equivocada. A conduta ilícita praticada na internet, conforme veremos adiante, tem o mesmo enquadramento jurídico da conduta ilícita praticada no ambiente social físico. Equivocada também é a aparente invisibilidade do internauta que pratica a conduta supondo que não será descoberto, pois existem modernos meios de investigação, com os quais a polícia conta para identificá-lo. Nos últimos anos cresceu bastante o número de ações judiciais que buscam a condenação, no âmbito cível e penal, de indivíduos que utilizaram a internet para cometer ilicitudes.

Os chamados crimes virtuais fazem uso da mesma metodologia adotada nos crimes já conhecidosem nosso ordenamento jurídico penal, os não-virtuais. O que diferencia é a técnica empregada, porém, a finalidade que se pretende é a mesma da conduta já tipificada.

A intenção do agente criminoso pode ser de enganar uma pessoa para obter uma vantagem financeira ou pessoal, enganar suas vítimas ou mesmo furtar informações particulares com o intuito de utilizá-las em proveito próprio ou tudo isso junto. Normalmente, quando alguém começa a cometer crimes virtuais, inicia essa prática, cometendo crimes mais leves e vai progredindo de maneira que o próprio agente sentirá dificuldade em interromper essa sequência.

Embora as condutas ilícitas mais comuns em ambiente virtual sejam de ameaça, de pedofilia e de violação aos direitos da personalidade-tipificadas criminalmente como calúnia, injúria ou difamação, que geram, civilmente, o direito à indenização por danos morais à vítima - outras também previstas no Código Penal e na legislação extravagante admitem a prática em ambiente virtual, como a instigação ao suicídio, o estelionato e a fraude.

Convém salientar também, o dever do Estado em apurar e proceder com a efetiva condenação dos indiciados. Neste ponto, é preciso destacar a criação de Delegacias Especializadas em crimes cibernéticos ${ }^{4}$, em alguns Estados da federação. Essa iniciativa aliada às discussões sobre a possível 
existência de varas judiciais igualmente especializadas para a tramitação de processos decorrentes de atos ilícitos cometidos na internet, está dando resultados positivos.

Cumpre destacar, que as consequências desse tipo de iniciativa suscitam questões permeadas de controvérsiasjurídicas, algumas analisadas a seguir.

No tocante à responsabilização dos provedores de internet, que disponibilizam, de modo até indiscriminado, os espaços virtuais e, de forma indireta, disseminam os eventos delitivos à sociedade, o Superior Tribunal de Justiça, em decisão ${ }^{5}$ proferida em 2011, consolidou o entendimento já reconhecido pelo Direito Internacional de que não há responsabilidade objetiva dos provedores em relação aos atos ilícitos praticados por alguns usuários. ${ }^{6}$

Essa orientação, em consonância com o Direito civil, fundamenta-se em que o contrato, tácito ou formal, de prestação de serviços não contempla a averiguação prévia do conteúdo a ser disponibilizado, ditando regras sobre o que poderia ser feito ou não, pois se assim o fosse, poderia vir a se configurar numa espécie de censura. A responsabilidade (seja ela penal ou civil) do provedor somente poderá ser confirmada se fícar comprovada omissão culposa ao não retirar o conteúdo ou material publicado, mesmo após ser notificado da ilicitude deste.

Nesse ponto, a jurisprudência ainda está bastante dividida acerca do seguinte aspecto: uma simples comunicação do fato junto ao provedor por qualquer pessoa é suficiente ou tal notificação deve ser, necessariamente, judicial? Em obediência à segurança das relações jurídicas e à própria liberdade de expressão, o que parece mais acertado e corrobora com o que está contemplada na Lei Ordinária 12.965/2014, que estabelece princípios, garantias, direitos e deveres para o uso da Internet no Brasil ${ }^{7}$ é a necessidade de a notificação ser de fato, judicial. E, em hipótese alguma essa medida significa uma judicialização no processo de comunicação dos sujeitos ou um dispositivo jurídico para impedir as pessoas de manifestarem suas opiniões abertamente, mas, tão somente uma forma de proteger essas mesmas pessoas que reclamam que estão tendo o seu direito de se comunicar cerceado.

Mesmo com a tramitação da Lei 12.965/14, a recente jurisprudência do Superior Tribunal de

\footnotetext{
${ }^{5}$ RESP n ${ }^{\text {o } 1.186 .616 / M G, ~} 3^{\text {a }}$ Turma, Relatora Min. Nancy Andrighi, publicado no Dje de 31/08/2011

${ }^{6}$ Um caso paradigmático e pioneiro que revela o princípio geral de que o provedor não pode ser responsabilizado objetivamente pelas mensagens que são disponibilizadas é o CubbyInc vs. CompuServe, julgado pela Corte Distrital de Nova Iorque em 1991. Para conhecer os detalhes do caso acessar o site: http://en.wikipedia.org/wiki/Cubby,_Inc._v._CompuServe_Inc.

${ }^{7}$ Art. 1912.965/2014. "Com o intuito de assegurar a liberdade de expressão e impedir a censura, o provedor de aplicações de internet somente poderá ser responsabilizado civilmente por danos decorrentes de conteúdo gerado por terceiros se, após ordem judicial específica, não tomar as providências para, no âmbito e nos limites técnicos do seu serviço e dentro do prazo assinalado, tornar indisponível o conteúdo apontado como infringente, ressalvadas as disposições legais em contrário.” Disponível em http://www.normaslegais.com.br/legislacao/lei-12965-2014.htm. Acesso em 16maio 2020.
} 
Justiça, todavia, vem decidindo pela necessidade de retirada imediata do conteúdo após qualquer comunicação, isto é, sem a necessidade de uma notificação judicial. Vejamos o que diz a ementa do RESP $\mathrm{n}^{\mathrm{o}}$ 1.186.616/MG: "Ao ser comunicado de que determinado texto ou imagem possui conteúdo ilícito, deve o provedor agir de forma enérgica, retirando o material do ar imediatamente, sob pena de responder solidariamente com o autor direto do dano, em virtude da omissão praticada".Além de ir de encontro com a jurisprudência do STF, essa decisão, claramente poderia se configurar numa espécie de censura a posteriori por pessoas destituídas de legitimidade para tal investigação.

De acordo com Silva (2012), a Constituição da República determina que seja dajustiça federal a competência para julgar e processar os feitos que, iniciados no Brasil, transcende o território nacional.

Entendimento semelhante pode ser encontrado em Precedente do Superior Tribunal de Justiça, prelecionando que a abrangência internacional de domínios ou de redes sociais é circunstância suficiente para a determinação da competência da justiça federal ${ }^{8}$. No entanto, cabe observar que esta orientação pode atrair a competência da justiça federal para todo e qualquer crime previsto em norma internacional, ainda que cometido entre vizinhos, em redes sociais populares como o facebook e, isso provocaria um verdadeiro inchaço na Justiça Federal.

O foro do ilícito penal será o juízo do local onde a ação delituosa ocorreu, ou seja, onde se encontrava o acusado, responsável pela publicação do ato ilícito no ambiente virtual.No caso do ato ilícito ocorrer em um site específico, caberá ao provedor agir de forma enérgica, comunicando ao site que determinado texto ou imagem possui conteúdo ilícito, devendo retirar o material do ar imediatamente, sob pena de responder solidariamente com o autor direto do dano, em virtude da omissão praticada.

Em relação ao ilícito civil, o entendimento do Superior Tribunal de Justiça ${ }^{9}$ é de que, no ciberespaço, o conceito de "lugar do ato ou fato" previsto no diploma processual civil é a localidade em que residem e trabalham as pessoas prejudicadas, pois seria na comunidade onde elas vivem que o evento negativo tem maior repercussão. Observe-se que não há menção em relação ao ofensor, pois todas as atenções se voltam para as vítimas e todas as consequências advindas do ato.

Existem crimes em que o intuito da pessoa que comete é o de demonstrar a fragilidade de alguns sistemas, como é o caso das recentes invasões às páginas de órgãos oficiais ou sistemas de bancos. Nesta modalidade o criminoso é motivado por uma questão de desafiar a segurança de sites do governo. Na maioria das vezes, sua intenção não é de beneficiar-se com o resultado finalístico do crime, mas, de provar que é um "expert" no assunto e, ainda consegue enxergar a possibilidade de ser contratado pelo mesmo

${ }^{8} \mathrm{CC} \mathrm{n}^{\mathrm{o}} 112.616 / \mathrm{PR}, 3^{\mathrm{a}}$ Seção, Relator Min. Gilson Dipp, publicado no Dje de 01/08/2011.

${ }^{9} \mathrm{AgRg}$ no $\mathrm{Ag} \mathrm{n}{ }^{\circ}$ 808.075/DF, Relator Min. Fernando Gonçalves, publicado no DJ de 17/12/2017 
órgão que invadiu. Na verdade, existem profissionais altamente capacitados que de fato são contratados por uma determinada empresa, com o único objetivo de que ele descubra as falhas e fragilidades do sistema de segurança virtual utilizado, criando mecanismos que impeçam que outros profissionais tão habilitados quanto ele, invadam o sistema e os dados dos clientes da empresa para qual trabalha.

$\mathrm{Na}$ verdade, existe uma infinidade de crimes virtuais, muitos ainda nem possuem um modus operandi conhecido, outros sequer foram descobertos, mas estão sendo praticados cotidianamente e fazendo muitas vítimas. Diferente do Brasil, outros países já estão muito avançados em relação aos crimes virtuais, inclusive com seu ordenamento jurídico atualizados em relação aos mesmos. Não restam dúvidas quanto ao fato de que as polícias científicas brasileiras necessitam urgentemente se aperfeiçoar para tentar primeiramente descobrir quem são esses sujeitos que agem no anonimato na internet, de onde, como são e com qual frequência são realizadas tais operações e principalmente como puni-los.

A legislação pátria necessita de uma reformulação no sentido de se adequar a essa nova realidade que já se configurou como uma tendência mundial e, não precisar recorrer a analogias jurídicas, como estão fazendo os magistrados nos mais diferentes tribunais, com o intuito de adequar a conduta delituosa do criminoso "virtual” àquela já prevista na legislação penal ou civil.

Como já vimos, o poder judiciário brasileiro utiliza os crimes já tipificados em nosso ordenamento para adequar os crimes virtuais. Os magistrados, em sua maioria, fundamentam seus julgados utilizando o artigo 171 do código penal, in verbis:“Artigo 171: Obter, para si ou para outrem, vantagem ilícita, em prejuízo alheio, induzindo ou mantendo alguém em erro, mediante artifício, ardil, ou qualquer outro meio fraudulento".

Conforme se verifica o artigo supra é bem amplo e abrange algumas modalidades de crimes virtuais. Outros crimes, como no caso da pedofilia são enquadrados no Estatuto da Criança e do Adolescente (ECA). Outros crimes não podem ser enquadrados em nenhum outro delito já tipificado, pois em nosso ordenamento penal a analogia propriamente dita só poderá ser utilizadanos casos em que o réu seja beneficiado, o mesmo se aplica à retroatividade penal.

A hipotética "analogia" utilizada pelos magistrados em seus julgados, pode ser caracterizada como uma interpretação mais extensiva no delito tipificado. Ainda que o local do crime não seja propriamente físico, mas por analogia existe, sobretudo,se o resultado buscado pelo criminoso ao cometer tal conduta na internet fora alcançado. Nestes termos, não se pode falar em lacuna na lei ou de que o criminoso não será punido por ausência de previsão legal, de modo, que restam pouquíssimos delitos cometidos na internet que não podem ser de nenhuma forma vinculados aos crimes já tipificados.

Portanto, o Brasil precisa urgentemente criar uma legislação específica para crimes virtuais, com 
o objetivo de colocar definitivamente "freios" nestes agentes que usam as redes sociais com o deliberado intuito de cometer os mais diversos tipos de condutas ilícitas. O uso da internet é algo sem volta, sobretudo, pelo fato de que ela tornou-se um livre comércio, que possui todo tipo de transação, onde tudo se vende e tudo se troca, inclusive as ideias. Indispensável para a sociedade de um modo geral, não podendo ser-lhe atribuída apenas o caráter de lazer, como era nos primeiros anos do seu surgimento, mas sim, com uma característica informacional, de trabalho e de entretenimento.

Os usuários (internautas) por sua vez, precisam conhecer mais sobre esses novos crimes, sobre a metodologia empregada pelos criminosos e desenvolver mecanismos de prevenção contra eles, alertando, sobretudo, as crianças e os adolescentes, que normalmente são as vítimas mais vulneráveis. Acerca dessa questão falaremos mais adiante.

\subsection{Os crimes mais comuns ocorridos na internet: É possível escapar deles?}

Segundo dados do IBGE (2018), com 94,2 milhões de pessoas utilizando a internet no Brasil e $45 \%$ delas usando redes sociais diariamente, não é difícil imaginar que algumas pessoas encontrembrechaspara roubar dados. Segundo o Indicador Serasa Experian de Tentativas de Fraude ${ }^{10}$, em levantamento realizado em 2018, a cada 15 segundos, um brasileiro é vítima de fraudes com documentos roubados ou informações furtadas na rede. A consequência disso é que mais de 28 milhões de pessoas foram prejudicadas por cibercrimes, dando um prejuízo ao país,em torno de R $\$ 16$ bilhões somente em 2017.Esses dados evidenciam claramente como é frágil e ainda insuficiente, a legislação específica bem como as medidas tomadas para evitar essas infrações penais.

As maneiras mais comuns disso acontecer são através do phishing (conversas ou mensagens falsas com links fraudulentos), spam (mensagens enviadas sem o consentimento dousuário) e malwares (softwares maliciosos instalados sem permissão do usuário, como vírus).

Conforme aponta o infográfico da Bitdefender ${ }^{11}$, os locais em que mais se compartilham links maliciosos são nas redes sociais e, quando esses links são clicados, podem provocar à instalação no computador, de programas nocivos. Os próximos do ranking são a pornografia e banners de publicidade.

\footnotetext{
${ }^{10}$ Disponível em: https://180graus.com/geral/brasileiro-e-alvo-de-tentativa-de-fraude-a-cada-16-segundos-revela-serasa. Acesso em: 08 dez 2019.

11 Dados extraídos do site: http://www.techtudo.com.br/noticias/noticia/2013/08/conheca-os-crimes-virtuais-maiscomuns-em-redes-sociais-e-proteja-se.html>. Acesso em: 9 fev. 2019.
} 
Quando um equipamento é invadido, o fraudador terá acesso a informações pessoais e sigilosas armazenadas, tais como: fotos, mensagens de e-mails, senhas de bancos, vídeos, etc. As principais consequências são o roubo de informações (inclusive sigilosas) e danos às máquinas.

Para se proteger, é necessário ter muita cautela ao clicar em links na internet. Cada pessoa deve ter o cuidado de digitar o endereço da rede social no browser, evitando, principalmente, clicar em links duvidosos que reencaminham o usuário para outro site. Na hora de aceitar amigos nas redes sociais, ter mais atenção. Esse cuidado garante que as suas informações só serão compartilhadas com quem o internauta realmente conhece. Afinal, saiba que, com raras exceções, tudo o que é publicado nas redes sociais acaba ficando disponível permanentemente na internet para os contatos.

Indubitavelmente, os crimes que envolvem as relações de consumo são os que ocorrem com maior frequência na internet, talvez pela facilidade e comodidade que existe no momento da transação ou aquisição de um produto e, ainda pela facilidade no pagamento em razão do valor do produto ou pelos descontos que são oferecidos. Descontos, na maioria das vezes, bem abaixo do valor de mercado. A partir de agora, serão elencados os exemplos mais frequentes envolvendo crimes de responsabilidade civil e penal nas redes, bem como as penas que podem ser aplicadas.

Nos casos que envolvem a ausência de informação sobre a periculosidade de produto na publicidade feita pela internet considera-se crime, com pena de detenção de seis meses a dois anos e multa, prevista no artigo 63 da Lei 8.078/90.

Aqueles que cometem crime de publicidade falsa ou enganosa de produto podem responder pelos artigos 66 e 67 da Lei 8.078/90, com pena de detenção de três meses a um ano e multa. Esse tipo de conduta tem sido cada vez mais frequente nas compras feitas pela internet. Ele se concretiza quando a vítima compra um produto com determinadas características, modelo, marca e especificação, paga por ele, mas recebe outro totalmente diferente. Existem muitos relatos de pessoas afirmando terem comprado um celular ou tablet e receberam um tijolo em substituição.

A falta de correção de informação errada sobre consumidor em cadastro, banco de dados, fichas ou registros também é considerado um crime virtual previsto no artigo 73 da Lei 8.078/90, com pena de detenção de um a seis meses e multa.

Não custa nada lembrar que na maioria das vezes, os internautas são atraídos pelos descontos e valores que estão cobrando em troca da entrega do produto. Destaca-se, que no caso dos crimes previstos na Lei 8.078/90, a ação penal é pública, cabendo ao Ministério Público oferecer denúncia e solicitar a abertura de inquérito. 
Cabe aqui um esclarecimento sobre o que vem a ser ação penal pública e privada e de quem é a competência. Os crimes de ação penal pública incondicionada (representem a quase totalidade) são aqueles em que o Ministério Público não possui discricionariedade e conveniência sobre a ação, devendo dar início à persecução criminal sempre que estiverem presentes indícios suficientes de autoria e prova da materialidade do crime, não necessitando de qualquer solicitação ou autorização para iniciar o processo (ESTEFAM, 2019). A investigação criminal, nessas situações, é sempre destinada ao Ministério Público (e não ao juiz, como parte da imprensa e da polícia divulga, equivocadamente). Nesse tipo de ação, o MP decide qual medida caberá. Nesse aspecto, reputa-se importante considerar as alterações advindas da Lei $13.964 / 2019^{12}$, sobretudo, àquelas que dizem respeito à conduta dos órgãos e agentes de investigação no tocante aos crimes cibernéticos.

Ultimamente uma modalidade de crime que vem se tornando muito comum na internet é o envio de e-mail derivado de algum órgão governamental, a exemplo da Receita Federal, do TSE, do Serasa e até da Polícia Federal. O modus operandi adotado é enganar a pessoa a quem se destina o e-mail, informando acerca de alguma pendência com o órgão. A mensagem também esclarece que a pessoa deverá clicar no link para solucionar tal situação ou até mesmo para saber mais detalhes sobre o fato. Ao clicar, o usuário é redirecionado para uma página que tem como objetivo a instalação no PC da vítima de um programa conhecido como sanguessuga. Logo depois desse procedimento, o criminoso começa a ter acesso a dados sigilosos.

Um processo semelhante ocorre com as vítimas que possuem laço com alguma instituição financeira. Ao clicar no link contido no e-mail, o usuário é direcionado a uma falsa página do Banco, onde é orientado a digitar seus dados bancários para uma suposta atualização bancária. Feito isso, o criminoso recebe todos esses dados e com isso pode efetuar diversas transações bancárias lesando a vítima.

Outra espécie de crime que pode e, na verdade ocorre com bastante frequência pela internet é o de ameaça. Este crime tem previsão legal no artigo 147 do Código Penal. Conforme prevê o dispositivo, a prática delituosa se configura quando alguém comunica a outra pessoa a intenção de lhe causar algum mal injusto e grave. A ameaça pode ser feita por palavra, por escrito, por gesto ou por qualquer outro meio. Nesses casos, é muito comum que a pessoa ofendida, silencie acerca das ameaças, por medo que estas sejam cumpridas.

Ainda em relação a esse crime, a lei exige que o mal anunciado na ameaça seja injusto o suficiente para que possa ser enquadrado como um crime. Desse modo, em princípio, não constitui ameaça quando uma pessoa diz que processará alguém, que irá levá-lo à justiça, ao Ministério Público ou à polícia, que

\footnotetext{
${ }^{12}$ Para mais informações, recomenda-se a leitura dos artigos 10 e 11.
} 
cobrará seus direitos, que contratará advogado para tomar providências, e outras afirmações do tipo. Nesses casos, não foi configurado nenhum mal injusto na ameaça, mas apenas a informação da pessoa de que exercerá os direitos que tem como cidadão.

Apesar de ser uma conduta repudiante e desprezível, a pedofilia é um crime que ocorre com alta e assustadora frequência na internet. Ele se concretiza quando uma pessoa adulta explora sexualmente criança ou adolescente ou quando produz ou troca imagens sexuais de criança ou adolescente. Esses crimes podem ser cometidos de variadas maneiras e estão definidos nos artigos 240 a 241-D do Estatuto da Criança e do Adolescente.

Os crimes estão previstos na Lei 8.069, de 13 de julho de 1990, conhecido como ECA. A título de exemplo, elegeu-se alguns artigos da mencionada lei a fim de mostrar como estes crimes estão configurados, bem como, o tipo de punição que é aplicado.

Conforme o art. 240 do ECA, cometerácrime quem produzir, reproduzir, dirigir, fotografar, filmar ou registrar, por qualquer meio, cena de sexo explícito ou pornográfica, envolvendo criança ou adolescente - pena de reclusão, de quatro a oito anos, e multa.

Poderá ser incurso na mesma pena, quem “vender ou expor à venda fotografia, vídeo ou outro registro que contenha cena de sexo explícito ou pornográfica envolvendo criança ou adolescente - pena de reclusão, de quatro a oito anos, e multa" (art. 241 da Lei 8.069/90).

O artigo 241 já é mais explícito, quanto aos crimes de internet, pois o art. 241-A: menciona que constitui em crime quem: oferecer, trocar, disponibilizar, transmitir, distribuir, publicar ou divulgar por qualquer meio, inclusive por sistema de informática ou telemático, fotografia, vídeo ou outro registro que contenha cena de sexo explícito ou pornográfica envolvendo criança ou adolescente, com pena de reclusão, de três a seis anos, e multa. E o art. 241-A, $\S 1^{\circ}$ adverte que comete o mesmo crime quem assegure os meios ou serviços para o armazenamento das fotografias, cenas ou imagens ou o acesso por rede de computadores às fotografias, cenas ou imagens, isto é, quem facilita ou colabora com o armazenamento ou divulgação do material pornográfico, ainda que não seja ele quem publique diretamente na internet ou outro meio eletrônico. Só o fato de conhecer o teor das imagens e não se opor a armazená-las já implica numa conduta criminosa, pois, o agente deveria saber que não está agindo corretamente e, além de se recusar a colaborar nesta empreitada criminosa, ainda tem a obrigação de denunciar o intento de quem pretende agir dolosamente.

Os artigos 241-C e 241-D, respectivamente, considera como crime àquela conduta que comprove que alguém venda, exponha à venda, disponibilize, distribua, publique ou divulgue por qualquer meio, adquira, possua ou armazene o material e ainda, aliciar, assediar, instigar ou constranger, por qualquer 
meio de comunicação, criança, para com ela praticar ato libidinoso. Quem infringir em ambas as condutas será punido com pena de reclusão, de um a três anos, e multa.

Então, como é possível constatar nesta breve discussão acerca dos crimes de pedofilia, o legislador enquadrou praticamente, todas as condutas que julgou criminosas em relação a este delito, condenando os algozes que insistem em infringir regras e condutas vedadas por lei, ainda mais, quando as vítimas envolvem crianças; que ainda não tem o total discernimento, tampouco consegue avaliar ou mensurar a dimensão e consequências disso, pela própria condição de vulneráveis que são.

Muitas vezes, a criança se deixa fotografar ou filmar, sem nem se dar conta de que aquelas imagens terão um mau uso, ainda mais, porque geralmente quem faz esses registros são pessoas do círculo de amizades da criança ou alguém que já faz parte do cotidiano, entre eles, os próprios pais, irmãos, tios ou tias, vizinhos, conhecidos da família, alguém da escola. Por essa razão, raramente a criança, dependendo da faixa etária e do grau de maturidade que possui, irá se recusar a postar para as fotos. Evidentemente, se se tratar de fotos ou vídeos sensuais ou cenas explícitas de sexo em que a criança esteja sem roupa, é preciso verificar como estes foram obtidos e em que circunstâncias, pois se ficar provado que a criança foi obrigada a agir contra sua própria vontade e sob ameaça, o crime poderá ser agravado.

No entanto, é preciso deixar claro, que o simples acesso a sites com conteúdo pornográfico, feito por pessoa adulta, não é crime, salvo se se tratar de site com imagens de crianças e adolescentes ou se o site promover outra espécie de crime (extorsão, ofensas à honra de terceiro, violência etc.). Não é ilegal, portanto, que pessoa adulta assista a vídeo ou consuma material pornográfico que envolva apenas sexo entre pessoas adultas, com o consentimento legítimo destas.

Outro ponto importante é que muitas pessoas ainda têm dúvidas sobre o assunto e não sabem reconhecer um crime virtual, e acabam sendo vítimas por não saberem como agir.

Como vimos, muitos usuários cometem deslizes nas redes, revelando dados pessoais para pessoas totalmente desconhecidas. Ao fazer isso, elas compartilham informações valiosas como: endereço particular, e-mail pessoal, data de nascimento, nome de solteiro e muitas outras informações que podem ser usadas por pessoas mal-intencionadas.

\section{Da "criminalidade virtual"}

Na década de 1960 apareceram os primeiros casos de crimes informáticos na imprensa e literatura científica. Pela primeira vez foi divulgada a utilização do computador para a prática de delitos, constituídos por manipulações, sabotagens, espionagem e uso exacerbado de computadores e sistemas. Após uma 
década do surgimento, iniciaram-se os estudos sistemáticos e científicos, com emprego de métodos criminológicos, estudando-se um número restrito de delitos informáticos denunciados, entre os quais alguns de grandes reflexos na Europa, por envolverem empresas mundialmente famigeradas. Já em 1980 houve crescimento de ações criminosas incidentes em manipulações de caixas bancárias, pirataria de programas de computador e abusos nas telecomunicações, deixando transparecer vulnerabilidades que os criadores do processo não previram. Acresce-se aqui o delito de pornografia infantil na rede, comumente disseminado na época.

Essa criminalidade, no entender de Luiz Flávio Gomes (2003, p. 68-9):

(...) conta com as mesmas características da informatização global: transnacionalidade todos os países fazem uso da informatização (qualquer que seja o seu desenvolvimento econômico, social ou cultural); logo, a delinquência correspondente, ainda que em graus distintos, também está presente em todos os continentes; universalidade - integrantes de vários níveis sociais e econômicos já têm acesso aos produtos informatizados (que estão se popularizando cada vez mais); ubiquidade - a informatização está presente em todos os setores (públicos e privados) e em todos os lugares.

Dentro desse contexto reconhece-se, como fator criminógeno, que a informática é permissiva quanto ao cometimento de novos delitos e potencializa outros tradicionais, exemplificando, o estelionato. Sendo assim, os crimes podem ser cometidos com o computador. A conceituação de crimes digitais fornecida por Corrêa (2003, p. 69) é de "todos aqueles relacionados às informações arquivadas ou em trânsito por computadores, sendo esses dados acessados ilicitamente, usados para ameaçar ou fraudar". Ao analisar esta definição, detecta-se que há menção aos crimes cometidos contra o computador, mas não só contra as informações e programas nele contidos, como também contra as informações e dados em trânsito por computadores, com o dolo de ameaça e fraude, não atingindo os crimes realizados com o computador, contudo, cujo bem tutelado pelo ordenamento jurídico é diverso, como ocorre com a pedofilia.

Em uma segunda corrente, Pinheiro (2001, p. 18-9) classifica os crimes informáticos ou cibernéticos em três categorias: virtuais puros, mistos ou comuns. $\mathrm{O}$ crime virtual puro seria toda e qualquer conduta ilícita que tenha por objetivo exclusivo o sistema de computador, o equipamento e seus componentes, inclusive dados sistemas. Crime virtual misto seria aquele em que o uso da internet é condição sinequa non para a efetivação da conduta, embora o bem jurídico visado seja diverso do informático, como, por exemplo, as transferências ilícitas de valores em uma homebanking ou no chamado salamislacing, onde o cracker retira de milhares de contas correntes, diariamente, pequenas quantias que correspondem a centavos e as transfere para uma única conta. Embora esses valores sejam ínfimos para o 
correntista, que, na maioria das vezes, nem se dá conta do furto, representam para o cibercriminoso uma expressiva quantia em seu montante. Por derradeiro, crime virtual comum seria utilizar a internet apenas como instrumento para a realização de um delito já tipificado pela lei penal. Assim, a Rede Mundial de Computadores acaba por ser apenas mais um meio para a realização de uma conduta delituosa.

Se antes, por exemplo, o crime como o de pornografia infantil (art. 241 do ECA) era instrumentalizado por meio de vídeos ou revistas, atualmente, dá-se por salas de bate-papo, ICQ, como também pela troca de fotos por e-mail entre pedófilos e divulgação em sites. Mudou a forma, mas a essência do crime permanece a mesma. Para Ferreira (2003, p. 69), a definição para crime de informática é "toda ação típica, antijurídica e culpável, cometida contra ou pela utilização de processamento automático de dados ou sua transmissão".

O conceito de ação funda-se em comportamento humano comissivo ou omissivo correspondente ao modelo previsto em lei como crime (típico), com a respectiva penalidade, atentado ao princípio da legalidade que direciona o Direito Penal, acrescendo-se o conceito de crime se a conduta ilícita e a responsabilidade penal puderem ser atribuídas ao agente. A autora adota a classificação proposta por HervéCroze e Yves Biscunth (2003, p. 69), na qual os crimes de informática distinguem-se em duas categorias: 1) os atos dirigidos contra um sistema de informática, por qualquer motivo, verdadeiro núcleo da criminalidade informática, por se tratarem de ações que atentem contra o próprio material informático (suportes lógicos ou dados dos computadores); 2) Os atos que atentem contra os valores sociais ou outros bens jurídicos, cometidos através de um sistema de informática, que compreenderia todas as espécies de infrações previstas em lei penal.

Entrementes, cabe ressaltar a preocupação existente acerca da tipificação jurídico-legal em que se inserem os crimes praticados na web, bem assim a correspondente imputação delitiva, a ponto de se admitir, por parte da doutrina, que nosso atual modelo penal encontra desprovido de mecanismo jurídico regulador e sancionador a tais condutas, conforme assinalamos. A respeito, outra não é a lição de Ramalho Terceiro (2011, p. 01): "Denota-se que para a sua caracterização, o crime necessita de: a) uma tipifícação expressa como crime por lei b) conduta (comissiva ou omissiva) c) que sendo expressa como tal, esteja válida ou apta a surtir efeitos perante todos (erga omnes)". Diz-se, assim, que é o tipo penal, ou seja, a conduta considerada como atentatória à norma.

Pressupõe e escora tal posicionamento no fato de que se faz necessário a tipificação específica em norma penal da capitulação jurídica correspondente, em observância ao princípio maior da legalidade penal, pelo qual não há crime sem lei anterior que a preveja. Ainda em contínuo ensinamento, assim pondera o mesmo e renomado autor, afirmando que a teoria da tipicidade visa classificar as condutas 
humanas em normas penais proibitivas ou em normas negativas, incriminando todos os fatos que possam estar desviados de uma conduta aceita socialmente. "Para os transgressores dessas normas, impõe-se uma sanção penal, que é geralmente a pena privativa de liberdade” (2011, p. 02).

Sem dúvidas, o computador e a internet colocaram nas mãos de criminosos novos instrumentos para a prática de atos ilícitos, atingindo bens e interesses que o Estado deve tutelar, coibindo agressões contra tais bens através de penas privativas de liberdade, pela força coercitiva do Direito Penal; desde 1960 que começaram a surgir os primeiros casos de uso do computador para a prática de crimes como o de sabotagem, chantagem e espionagem. Na década de 80 os crimes se ampliaram para o de estelionato, furto de dinheiro em contas bancárias, introdução de "vírus" em computadores (crime de dano), tráfico de drogas, sonegação fiscal e desrespeito aos direitos autorais.

Tornou-se preciso não só proteger esses bens com mais segurança contra invasões (senhas, criptografia), como também elaborar leis tipificando essas condutas (de preferência uma leiinternacionalaprovada em tratado), afinal não há crime sem lei anterior que o defina; em alguns casos os crimes são os mesmos já conhecidos, apenas executados de nova maneira; em outros casos é preciso nova tipificação penal. Deve-se analisar com cuidado a legislação penal já existente para tipificar os cybercrimes, e não apenas se acomodar com a possível falta de lei para não punir o criminoso digital.

O Cybercrime é o crime que utiliza um sistema de informática para atentar contra um bem juridicamente protegido, seja tal bem público ou privado. Listamos alguns crimes tipificados que podem ser praticados pela internet, são eles: a) homicídio: o criminoso invade o computador da UTI de um hospital e altera os remédios de um paciente, levando uma enfermeira a matá-lo pela dosagem errada; b) crime contra a honra: caluniar, difamar ou injuriar alguém através de um site; c) instigação a suicídio através da troca de e-mails ou de mensagens instantâneas; d) furto: desvio de dinheiro em contas bancárias; e) estelionato: uso de CPFs e cartões de crédito falsos para fazer compras na internet; f) violar direito autoral através da cópia de softwares e músicas; g) Pedofilia - divulgação de pornografia infantil (art. 241 do ECA); h) Favorecimento de prostituição com um site anunciando garotas de programa; i) Tráfico de drogas e de armas que são anunciados pela internet.

Por óbvio, entrementes, ante a assombrosa e reconhecida evolução tecnológica, outras modalidades de crime certamente permearão nossa esfera jurídica, dentre as quais as hipóteses de "pixação eletrônica", "difusão de vírus" e "a pescaria e o estelionato com uso de redes", em distinta e precisa observância ao que explicita o Desembargador Fernando Neto Botelho (2011, p. 236): "Essa engenharia do mal, que monopoliza o conhecimento (da computação sofisticada e dos protocolos de redes), cresce à sombra da impunidade gerada pela insuficiência regulamentar de desatualizados instrumentos legais do 
país, como o Código Penal de 1941”.

No nosso entendimento não bastam apenas novas leis, pois os profissionais do direito e as autoridades policiais precisam estar preparados, equipados e treinados para apurar e reprimir a execução dos cybercrimes. Para isso é importante contar com a colaboração dos provedores, que devem priorizar os valores éticos sobre os comerciais, ajudando as autoridades a investigar seus clientes suspeitos da prática de crimes.

Portanto, mister maior análise, mesmo até como maneira de detida compreensão acerca da tipificação e imputabilidade respectiva, como mandamentos primários e substanciais da norma penal, com a ressalva de que também se mostra necessário, com redobrada permissão, o uso da interpretação adaptativa e teleológica a se atingir o viés objetivo jurídico enquanto do aguardo da resolução definitiva do Projeto de Lei n. 84/99 (Lei de Cybercrimes).

\subsection{O "Ciberbullying"}

Inegavelmente reconhecido como hipótese de cometimento de violência física, moral e psicológica entre crianças e adolescentes, inicialmente disseminadas apenas no âmbito escolar, o bullying praticado pela internet vem espantosamente aumentando a cada dia que passa, sobretudo pela irrestrita facilidade de acesso às ferramentas disponíveis nos modernos meios de comunicação. Assim, esta reconhecida expressão inglesa é utilizada para qualificar comportamentos agressivos de forma intencional e repetitiva, sem que, todavia, este nefasto comportamento transgressivo apresente qualquer plausível motivação específica e justificável, muito ao revés, apenas arrima no fato em se maltratar, intimidar, humilhar ou mesmo amedrontar vítimas, como puro e único "objeto de diversão".

A forma em que traduzida pela internet vem hoje sendo o modo mais usual de ocorrência, já que possibilita que agressões sejam provindas e praticadas anonimamente ou, quando no máximo, que seu praticante se camufle e esconda sua identidade por apelidos, tal como corrente por meio de messenger, email, instagran, twitter, facebook e outros sítios de relacionamento. Com o crescimento desenfreado, reflexos jurídicos vão se desencadeando gradativamente, exigindo incisiva resolução pela aplicação da legislação vigente, seja de ordem civil, seja de ordem penal, sem olvidar, nesse desiderato, a aplicação das disposições normativas do Estatuto da Criança e do Adolescente (ECA).

Conforme destacado por Márcio Morena Pinto (2011, p. 01), sem pretensos exageros, a rede internet tornou-se um verdadeiro paradigma para a rede de informação, uma forma universal caracterizada pela heterogeneidade e fluidez incessante, o que torna cada vez mais difícil encontrar um sentido global 
que permita circunscrever toda a fenomenologia do novo a uma suposta dominação. Daí a importância de se estabelecer um ramo jurídico com diretrizes próprias, produzindo-se reflexões jurídicas abrangentes e sistemáticas, tencionando esclarecer as novas práticas geradas com o advento da rede, legitimando-as e conduzindo-as gradativamente a uma possível regulamentação. A título penal, dependendo por óbvio da intenção do agressor, sua prática pode ser tipificada como hipótese de crime de ameaça, racismo, injúria, calúnia, difamação ou até lesão corporal. Em sede de aplicação do ECA, perfeitamente admissível a aplicação dos crimes descritos nos arts., 240 e 241-A, donde se verifica a busca pela proteção maior, como bem jurídico tutelado, da liberdade e dignidade da criança ou do adolescente.

$\mathrm{Na}$ seara civil, todo e qualquer ato desabonador danoso pode ensejar a aplicação indenizatória, mormente pelo ocasionado abalo moral, como modus operacional e educacional a balizar o infortúnio. Registre-se até a posição pela qual em casos que a responsabilização sopesaria cujo objetivo, não havendo que se comprovar o dolo como elemento caracterizador da ofensa. A toda sorte, mister o combate jurídico desta ofensiva prática delitiva, tal como corrente em outros ordenamentos, dentre eles o direito norteamericano e, entre nós, antecipadamente louvado pela Lei Estadual n. 14.651, de 12 de janeiro de 2009, editada pelo Estado de Santa Catarina, que propõe a instituição de um "Programa de Combate ao Bullying".

\subsection{O problema da prova nos crimes virtuais}

Desde que os crimes cometidos na internet começaram a surgir, um dos problemas que surgiu em decorrência dessa prática delituosa foi à questão da prova. Sabe-se que em qualquer caso de ato ilícito que possa causar responsabilidade civil ou penal para seu autor, a vítima sempre se depara com a necessidade de provar os fatos. Toda ação judicial precisa de prova para gerar condenação.

No caso de ato ilícito cometido pela internet, às vezes a prova é fácil, pois é possível gravar o texto, imagem, vídeo ou som que represente o ato. Isso pode ser feito diretamente pelo ofendido, por meio da gravação da imagem da tela do computador (pelo comando Print screen ou equivalente), pela gravação do email, pela impressão em papel (hardcopy) ou em formato PDF dos arquivos ou por qualquer outra forma.

A gravação dos dados pode ser feita pela vítima ou por outra pessoa que tenha conhecimento do fato, como, por exemplo, se o usuário de uma rede social vir ofensa a pessoa que não tenha acesso àquela mesma rede social.

Se o texto ou imagem ofensivo não estiver mais disponível no site ou programa onde foi lançado, 
existem ainda pelo menos duas possibilidades: (a) o advogado da vítima (ou o Ministério Público ou a polícia, conforme o caso) pode solicitar ao responsável pelo site ou programa que lhe envie os arquivos gravados em seus computadores; (b) a vítima pode indicar ao juiz pessoas que tenham tido conhecimento do ato e possam depor como testemunhas.

$\mathrm{Na}$ internet existe responsabilidade civil, afinal o ciberespaço não está fora da sociedade e do direito; quando ocorre um dano, deve-se atribuir a responsabilidade ou: 1) ao provedor (fornecedor dos serviços de internet e transmissor das mensagens por meio da rede, que tem responsabilidade objetiva pois sua atividade já representa um risco de ocasionar danos a terceiros, pois o provedor ignora muitas vezes o material que está fazendo trafegar, apesar de evidentemente não ser um leigo em tecnologia, que deve por isso investir em segurança, vide parágrafo único do art. 927 do CC), ou 2) aos usuários desses provedores (ex: bancos eletrônicos, supermercados virtuais), ou 3) ao próprio cidadão que cometeu o ato ilícito, ou 4) ainda aos três solidariamente.

É difícil muitas vezes identificar de onde partiu o ato ilícito, mas com competência, um perito em informática alcança o infrator; e o advogado não pode desconhecer o direito da informática para produzir provas em favor de seu cliente.

Os casos mais comuns de aplicação da teoria da responsabilidade civil na internet decorre de: a) fraudes bancárias: os bancos precisam sempre atualizar seus sites, investir em segurança e exigir dos clientes mais de uma senha; b) interrupção do acesso à rede: por problemas do provedor ou das linhas telefônicas, cabos e sinais de satélite que o provedor utiliza; c) invasão de privacidade: na internet há muita segurança (senhas, criptografia - escrita em código), mas há também ataques de "hackers" e seus vírus capazes de acessar e divulgar informações secretas das pessoas (ex: declaração do imposto de renda, endereço residencial, violação e alteração de e-mails, difamação, etc.), violando a intimidade, a vida privada, a honra e a imagem dessas pessoas - art. $5^{\circ}, \mathrm{X}, \mathrm{CF}$; o mérito do "hacker" é poder modificar dados de um site disponível apenas para leitura, gravando em seguida suas modificações no provedor; d) violação do direito autoral: a internet serve para utilizar e divulgar obras escritas, musicais e audiovisuais sem o respeito ao copyright.

\section{Posição jurisprudencial quanto à prática de crimes virtuais}

Convém mencionar que em instância superior, vem sendo rechaçada reiteradamente, a prática dos crimes cibernéticos, cuja resolução na esfera civil bem acaba por culminar na responsabilização e consequente aplicação de indenização a título de dano moral. Assim, exemplificativamente as ações são 
nominadas de: Indenização. Dano moral. Ofensas através de site de relacionamento na internet. Responsabilidade civil objetiva. Teoria do risco. Dever de indenizar. Quantum indenizatório. Fixação.

O provedor de serviço de internet, ao disponibilizar espaço em sites de relacionamento virtual, em que seus usuários podem postar qualquer tipo de mensagem, sem prévia fiscalização, e, ainda, com procedência, muitas vezes, desconhecida, assume o risco de gerar danos a outrem, sendo de se aplicar a eles a teoria do risco. O parágrafo único do art. 927 do Código Civil adota a teoria do risco, estabelecendo que haverá obrigação de reparar o dano, independentemente de culpa, nos casos especificados em lei, ou quando a atividade normalmente desenvolvida pelo autor do dano implicar risco para os direitos de outrem. Ao fixar o valor da indenização, deve-se ter em conta as condições do ofendido, do ofensor e do bem jurídico lesado ${ }^{13}$.

O operador do site, em regra, como no caso do twitter, não tem um controle editorial prévio, mas somente a posteriori, quando toma conhecimento do que foi efetivamente publicado. Por isso, somente pode ser responsabilizado quando tem conhecimento real do caráter ilícito ou algum motivo para desvendar a natureza da informação. É a partir deste momento, em que é informado do caráter danoso da informação hospedada em seu sistema, que tem a obrigação de tomar todas as medidas necessárias para prevenir danos ou retirá-la, sob pena de ser responsabilizado por negligência. [...]. (TJMG, 9a Câmara Cível, Apelação Cível n 1.0024.07.483036-5/001, Relator Des. Pedro Bernardes, j. em 07.04.2017).

Vejamos abaixo uma decisão jurisprudencial envolvendo casos de Indenização por danos morais.

Violação da honra objetiva. Configuração do dano moral à pessoa jurídica. Valor indenizatório. Proporcionalidade e razoabilidade. Recurso parcialmente provido. Ao escrever e divulgar o e-mail narrando fato ocorrido dentro do estabelecimento de dança, a requerida extrapolou os limites de um mero protesto e violou a esfera extra-patrimonial da autora. A pessoa jurídica, portadora de honra objetiva, faz jus à indenização por dano moral sempre que seu nome, credibilidade ou imagem forem abalados por ato ilícito. O magistrado não pode se afastar dos princípios da proporcionalidade e da razoabilidade no momento de fixar o valor da indenização por dano moral, servindo a indenização como instrumento de caráter pedagógico preventivo e educativo da reparação moral (TJDF, 20060110313453APC, Relator Des. Lécio Resende, $1^{\text {a }}$ Turma Cível, j. em 14.04.2010, DJ de 27.04.2010, p. 88).

Veja-se, pois, que, além da corrente posição acerca da responsabilização de ordem penal, que,

${ }^{13}$ (TJMG, 12a CC, Apelação Cível n 1.0091.08.011925-7/001, Rel. Des. Alvimar de Ávila, publ. em 26.04.2010). Indenização. Dano moral. Orkut. O prestador do serviço orkut responde de forma objetiva pela criação de página ofensiva honra e imagem da pessoa, porquanto abrangido pela doutrina do risco criado; decerto que, identificado o autor da obra maligna, contra ele pode se voltar, para reaver o que despendeu (TJMG. Ap. Cível $n^{\circ}$ 1.0701.08.221685-7/001. Relator: Des. Saldanha da Fonseca, j. em 05.08.2009). 
frise-se, requer atualizada normatização correspondente, à altura vem sendo aplicado o direito civil como forma de recompor o status quo ante, em vista do abalo moral ocasionado pela prática delitiva, cujo modo de operação vem incessantemente se realizando pela internet.

Caso interessante de condenação por ofensas feitas na internet foi julgado pelo Tribunal de Justiça do Distrito Federal. Um consumidor contratou curso de desenho gráfico, realizou-o, conseguiu aprovação, recebeu o certificado e, só depois, procurou a empresa para pedir a devolução do pagamento. Como não teve sucesso, registrou reclamação no Procon/DF e em um site de reclamações de consumidores, com expressões agressivas e ofensivas. Por entender que o consumidor exagerou e abusou do direito de reclamar, o tribunal condenou-o a pagar indenização à empresa pelas ofensas contra esta, conforme notícia na página da corte.

\section{Considerações Finais}

Ante nossa singela exposição, não há como negar a ascensão dos crimes na internet, tal como hodiernamente vem ocorrendo com o bullying virtual. Em que pese à inexistência de legislação penal específica, o Direito vem respondendo com celeridade e mesmo eficiência às demandas criminosas eclodidas, não se podendo olvidar a necessidade de capitulação jurídica de novas hipóteses delitivas que vêm sendo perpetradas pela web. Assim, o que se espera é que com a promulgação da Lei Ordinária 12735/2012, e posteriores alterações, as pessoas incursas nos crimes cibernéticos, respondam integralmente por suas condutas delitivas, vez que ao cometerem, deveriam igualmente ter ciência das consequências legais.

Corretamente, não se mostra de boa técnica, que o indivíduo que se sirva da internet de boa fé e legitimado a exercer seus direitos essenciais sofra pela desídia que em nada teve correlação delitiva, razão por que afirmativamente vem sinalizando a doutrina e jurisprudência em atribuir ao site-provedor à responsabilização em casos que tais, hoje ainda mais presente nas situações em que há intensa participação dos hackers ou dos crackers. Prevalece, pois, a manutenção dos direitos da personalidade, em consonância com a intimidade e privacidade, que em nenhuma situação ou circunstância admite seu açoitamento.

Pela aplicação do instituto da reparação civil, esculpida pelo Código Civil e pela Constituição da República, nosso país vem dando um grande salto no que concerne à obstaculização de transgressões lesivas pela internet, destacando-se, a toda evidência, a força imperativa advinda de nosso ordenamento jurídico.

Ao contrário do que pensa muita gente, a internet não é ambiente livre de regras jurídicas, onde as 
pessoas possam fazer o que desejem, sem enfrentar as consequências de seus atos. Em princípio, qualquer ato ilegal praticado por alguém na internet pode gerar consequências jurídicas. É o que se denomina de responsabilidade, ou seja, as pessoas podem ser responsabilizadas por seus atos na chamada rede mundial de computadores.

Nesse passo, de forma geral, poder-se-ia afirmar que a responsabilidade por atos na internet é idêntica àquela causada por atos no mundo físico, isto é, no mundo não virtual. Logo, não há norma jurídica que dê isenção às pessoas para praticar atos ilegais na internet.

Vimos neste artigo que a responsabilidade por ato praticado na internet pode surgir em qualquer das formas de utilização dela. Pode ocorrer em redes sociais, na troca de e-mails e arquivos, na negociação de um contrato, na compra de bens em lojas virtuais (o comércio eletrônico ou e-commerce), em blogs e em qualquer outro site ou forma de interação eletrônica, inclusive por meio de telefones inteligentes (os smartphones), tablets etc.

Isso não significa que as pessoas devam andar assustadas por usar a internet. Por si só, o uso normal da rede não gera responsabilidade alguma. Apenas se houver a prática de atos ilícitos, isto é, atos contrários às normas jurídicas, podem gerar a responsabilização de alguém.

Um mesmo ato ilícito pode gerar diferentes formas de responsabilidade, pois, no direito brasileiro, elas são relativamente autônomas entre si. Por exemplo, alguém pode causar dano a outra pessoa (o que gera responsabilidade civil) sem que isso seja crime (responsabilidade penal). As mais comuns são a responsabilidade civil e a penal.

Para cuidar da nova realidade, faz-se necessário, portanto, de uma legislação atualizada. A tecnologia, sozinha, não dará conta. Só a lei garante oportunidade de defesa e prova justa, próprias das democracias amadurecidas.

Nesse escopo, sem que se tenha qualquer pretensão de estagnar um assunto, extremamente complexo, apenas buscou-se contribuir e auxiliar para um maior aprofundamento da discussão em tela, tão usualmente corrente em nossa seara jurídica.

Por fim, uma vez mais, apenas cabe frisar que nosso país vem se destacando e se fortalecendo no combate às transgressões criminais expostas e correntes na web, muito embora esteja carente de uma legislação específica. 


\title{
CIVIL AND CRIMINAL LIABILITY ON THE INTERNET:THE ROLE OF THE BRAZILIAN JUDICIARY
}

\begin{abstract}
In recent years the internet has become an important tool in the process of communication between people, as well as in the accomplishment of the most varied business. Parallel to the benefits due to the reach achieved by it, a series of harms are also counted, above all, as regards its misuse. Simultaneously with the benefit of this service came the virtual crimes, however, the country legal order did not follow the speed of growth of the use of this important technology. There are bills waiting to be sanctioned for more than three years, and meanwhile, criminals are getting better every day. The result of this disparity is verified in the number of cases of injured persons and individuals responsible for these crimes. Thus, this article deals with civil and criminal liability related to the Internet, whose clipping rests on the conduct adopted by netizens in relation to some aspects, making virtual space a "land without law". It intends to discuss the meaning of civil and criminal liability and how the Brazilian courts have positioned themselves in relation to these crimes. The bibliographic review was used as a methodological contribution, as well as the hypothetical-deductive approach, based on the perception and theoretical understanding of a given problem. The result of this analysis showed that people need to be aware of the behaviors adopted on the internet and take responsibility for their actions, since no one is obliged to suffer any kind of offense or to be indifferent to it.
\end{abstract}

Keywords: Civil liability. Criminal responsibility. Internet.

\section{Referências}

BRASIL. Decreto Lei no 2.848, de 07 de dezembro de 1940. Código Penal. Brasília. Disponível em $<$ www.planalto.gov.br/ccivil_03/decreto-lei/del2848.htm> Acesso em: 06 de fev. 2019.

BRASIL. Constituição (2014). Lei no 12.965, de 23 de abril de 2014. Lei No 12.965, de 23 Abril de 2014: Estabelece princípios, garantias, direitos e deveres para o uso da Internet no Brasil.. Brasil, DF: DOU, 24 abr. 2014. Disponível em: http://www.planalto.gov.br/CCIVIL_03/_Ato20112014/2014/Lei/L12965.htm. Acesso em: 16 maio 2020.

BRASIL. Constituição (2019). Lei No 13.964, de 24 Dezembro de 2019: Aperfeiçoa a legislação penal e processual penal. Brasil, DF: DOU, 24 dez. 2019. Disponível em: http://www.planalto.gov.br/ccivil_03/_ato2019-2022/2019/lei/L13964.htm. Acesso em: 16 maio 2020.

CORRÊA, Gustavo Testa. Aspectos jurídicos da internet. São Paulo: Saraiva, 2000. p. 43.

DONEDA, Danilo César Maganhoto. Considerações iniciais sobre os bancos de dados informatizados e o direito à privacidade. In: TEPEDINO, Gustavo. Problemas de Direito Civil Constitucional. Renovar: Rio de Janeiro, 2000.

ESTEFAM, André. Direito Penal, volume 1. Parte geral (arts. $1^{\mathrm{o}}$ ao 120$) .8^{\mathrm{a}}$ ed. São Paulo, Saraiva vol.13,n' ${ }^{\circ} .01$,RiodeJaneiro,2020.pp. 480-507 
Educação, 2019.

FERREIRA, Ivette Senise. A criminalidade informática. In: LUCCA, Newton de; SIMÃO FILHO, Adalberto (Coords.). Direito e internet: aspectos jurídicos relevantes. Bauru: Edipro, 2000. p. 207-237.

GAMA, Remy. Crimes da Informática. Brasília: Copy Market. 2000.

GASPARIAN, Taís. Privacidade em tempos de internet. Revista do Advogado, ano XXIII, no 69, p. 37, maio 2013.

GOMES, Flávio Luiz. Crimes informáticos. Disponível em: www.direitocriminal.com.br. Acesso em: 26 nov. 2019.

GONÇALVES, Carlos Roberto. Direito Civil brasileiro: responsabilidade civil, IV. $4^{\text {a }}$ Ed. São Paulo: Saraiva, 2009.

GUIMARÃES, José Augusto Chaves; FURLANETO NETO, Mário. Crimes na internet: elementos para uma reflexão sobre a ética informacional. Revista CEJ, Brasília, ano VII, n. 20, p. 69, jan./mar. 2013.

LIMONGI FRANÇA, R. Manual de direito civil. 3. ed., Revista dos Tribunais, 1995.

PINHEIRO, Reginaldo César. Os crimes virtuais na esfera jurídica brasileira. São Paulo: IBCCRIM, v. 101, p. 18-19, abr. 2001 (separata). In: GUIMARÃES, José Augusto Chaves; FURLANETO NETO, Mário. Crimes na internet: elementos para uma reflexão sobre a ética informacional. Revista CEJ, Brasília, ano VII, n. 20, p. 69, jan./mar. 2003.

RAMALHO TERCEIRO, Cecílio da Fonseca Vieira. O problema na tipificação penal dos crimes virtuais. Jus Navigandi, Teresina, ano 7, n. 58, 1 ago. 2002. Acesso em: 29 nov. 2019.

SOSA, Marcelo Gonçalves. O bullying na Internet: alguns apontamentos jurídico-sociais. Disponível em file:///F:/Âmbito\%20Jurídico\%20-\%20Leitura\%20de\%20Artigo\%20-

$\% 20$ bulling\%20na\%20internet.htm. Acesso em: 16 maio 2020.

SILVA, Luis Gustavo Freitas da. Atos praticados na internet: responsabilização civil epenal. Revista Jus Navigandi, Teresina, ano 17, n. 3156, 21 fev. 2012. Disponível em: https://jus.com.br/artigos/21125. Acesso em: 17 maio 2020.

Tribunal de Justiça de Minas Gerais. Jurisprudências. Disponível em: www.tjmg.jus.br/juridico/jt_/index.jsp. Acessado em: 15 maio 2020.

ZULIANI, Ênio Santarelli. Reflexões sobre o novo Código Civil. Revista do Advogado, nº 68, Ed. AASP, dezembro/2012.

Trabalho enviado em 13 de abril de 2019 Aceito em 18 de maio de 2020 
Quaestio Iuris

vol. $13, n^{\circ} .01$, Riode Janeiro, 2020. pp. 480-507 DOI: $10.12957 /$ rqi.2020.41493 